\title{
Violence Against Women in Bangladesh and How We Can Prevent it?
}

\author{
Kaniz Tania Bint-E-Basar ${ }^{1}$, Dewan Md. Al-Amin ${ }^{1}$ \& Md. Mostofa ${ }^{1}$ \\ ${ }^{\mathbf{1}}$ Department of Law, Faculty of Arts, Social Science \& Law, Bangladesh University, Bangladesh \\ Correspondence: Kaniz Tania Bint-E-Basar, Department of Law, Faculty of Arts, Social Science \& Law, \\ Bangladesh University, Bangladesh, E-mail: ktbb2008@gmail.com, Tel: +88 01712184268
}

\section{Abstract}

This paper examines Violence against women (VAW) takes place in different sectors in Bangladesh. There are various types of violence in our country i.e. physical, sexual, domestic violence, killing, rape etc. Socio-Economic aspect also plays a pivotal role in violence against women. There are some common features of VAW like polygamy, extra-marital or pre-marital relations, lack of social and economic security, lack of proper education and cybercrime. Unemployment is also one of the main reasons of VAW in Bangladesh. Prevention measures should be taken by family, society and also by the state machine to prevent VAW. Implementation of domestic laws of VAW and monitoring system and social awareness will be the effective measures to prevent this criminal activity from the society and from the state.

Keywords: Violence against Women, Reasons behind the violence, Prevention of VAW, Enacted laws in Bangladesh.

\section{Introduction}

Violation against Woman (VAW) takes various forms such as discrimination, intimidation, harassment, torture and also physical abuse not simply from state organs but also from their own family and other private organizations. Violence and gender-based violence and typologies of violence range from emotional to physical and sexual violence. The vicious cycles of violence that a girl experiences begin from the womb (female infanticide, lack nutrition, and health care) to various stages of nutrition, rape, forced prostitution) to adulthood (dowry, killing, intimate partner violence, domestic violence )till old age (widow abuse). Status quo of gender-based violence indicates that $56 \%$ of women entered their marriage before they were 18 years old and $87 \%$ of women had experienced some form of violence at the hands of their current husbands. The incidence of physical and sexual violence experienced by married women where the perpetrators are their husbands stand at $65 \%$ and $36.5 \%$ respectively and only $77 \%$ of women reported violence at the hands of their husbands. Compared to urban areas, the prevalence rate of such incidences is higher in rural areas. In rural areas, $43 \%$ of unmarried adolescent girls are 
sexually harassed on their way to school, college or social visits (Alam, Roy, Ahmed 2009). Not only in our country but also in many parts of the world are regularly subjected to mental and physical violence or sexual abuse, such as incest, rape, dowry deaths, wife battering and forced sterilization.

\section{Literature Review}

Although violence by men against women in Bangladesh occurs in most cases within the home, in a larger sense it does not originate in the home nor persist only within the home. It is simply one element in a system that subordinates women through social norms that define women's place and guide their conduct. (Schuler, S. R., et al., 1996).

Using data from a population-based survey of 2,702 women of reproductive age and from 28 in-depth interviews of abused women conducted during 2000-01, this study explores factors associated with domestic violence in urban and rural Bangladesh. Multilevel analysis revealed that in both residential areas, dowry or other demands in marriage and a history of abuse of the husband's mother by his father increased the risk of violence. Better spousal communication and husband's education beyond the tenth grade decreased the risk of violence. In the urban area, women's being younger than their husband and participating in savings and credit groups increased the risk of abuse, whereas husband's education beyond the sixth grade had a protective effect. In the rural area, women's earning an income increased the risk. These factors are important to consider when designing interventions. (Naved, R. T., et al., 2005).

Violence against women has many forms including physical aggression or threats, sexual abuse, emotional abuse, controlling or domineering, intimidation, stalking, passive/covert abuse, and economic deprivations. Alcohol consumption and mental illness can be co-morbid with abuse and present additional challenges when present alongside patterns of abuse. (Khan, N. T., Begum, et al., 2017).

Violence against Women (VAW) is the most obvious gender-specific violation of Human Rights and is a form of discrimination against women [1]. It enforces women`s subordination and patriarchal structures throughout all levels of society, leading to issues such as the undervaluation of women`s economic contributions. VAW is not only embedded in gender norms; gender norms are also constructed through VAW, and "the low status of women economically, socially, culturally and politically both constitutes and enables the further denial of human rights in gender-specific ways, often at the hands of family members, male and female" (Reilly, 2009, p.78). Thus, VAW both reflects and determines gendered social structures (McMillan, 2007). That is why framing VAW as a Human Rights violation requiring immediate action is crucial to challenge the economic, social and cultural marginalization of women in Bangladesh.

\section{Research Methodology}

This research article is mainly based on qualitative method. Secondary source has been applied for this research article such as books, articles, journals, enacted laws, newspaper, media, national and international organizational functions and activities also help to interpret and to analyze data for this research article.

\section{Objective of the Research}

The objective of the study is to identify and know the reason of the VAW and its preventive measure and the implementation of the domestic laws for the breach of women rights. 


\section{Data Analysis and Interpretation}

\subsection{The Reasons behind VAW}

In view of the seriousness of violence against women noted above, this study makes an attempt to discern the causes of the problem. Additionally, it suggests some preventive measures.

Female, being bride has to face serious problems from the very beginning her family and conjugal life. Regrettably members of husband's family hardly understand these difficulties of the bride and as a result, it occurs various VAW. Some common victims of violence are

- Maidservants who become the victims of violence for want of moral, social and legal norm;

- Female employees who are being harassed at the workplace by their colleagues. Female students are being stalked by their classmates in the educational institutions;

- Domestic Violence which takes place from the time of entering the matrimonial house of women and in Bangladesh. It causes Dowry death, hurt, murder culpable homicide, suicide etc;

- Dower is women's right but dowry is prohibited.In practice, dower cause in a written form in marriage contract and wife can claim for the recovery of dower at any time.Unfortunately, there is no written document to recover the amount of dower from the husband. In addition to that, if women are incapable to fulfill the payment of the demanded dowry, she faces humiliation, mental torture, verbal and physical abuses, even murder by her husband and in-laws. Having known the victims of violence against women, it is important to maintain the dominant causes of the menace. Below are described some of the causes. Beside this the women's in our country are not aware of their rights, as a result, they are victim various violation of rights ;

First, Polygamy, extra-marital or pre-marital relationships are common causes of violence against women. Even after marriage, some people continue their previous relationship without caring about wife's emotional condition due to this. This leads to quarrels and eventually maltreatment by the husband.

Second, in Bangladesh, there are some social middle-class norms for which women subjected to violence remain silent because the society doesn't take the matter as a breach of rights or violation against a woman. There is no social and economic security on behalf of the women. Most of the time a woman is derived from her right by her husband, brother or nearest family members. As a result, the violation of rights begins with her own family.

Third, women in our country are not properly educated and independent and they have no freedom of speech or expression in the family thought she may play an important role in the family, society, and country.These are also an important cause of violation of women's rights.

Fourth, nowadays cyber crimes are of gender nature and they target men and women alike. But there are certain cyber crimes that are more likely to target women than their male counterparts. These include cyberstalking, cyber harassment, email/profile hacking, spoofing, cyber pornography including porn, internet voyeurism defamation, cyber blackmailing, threaten, emotional cheating by impersonation, intimate partner violence through internet and abetment of such offenses. Women's right in the cyberspace are abused in many ways in Bangladesh and use of internet and mobile phones to stalk, abuse, intimidate and humiliate women's rampant. 
Cyber Pornography which refers to pornography of sexual material on the web is another facet of cyber crimes. Criminals often rape or molest a girl, capture the incident by a web camera or mobile phone and spread the video over the internet. These incidents are becoming alarmingly common even in the rural area $\mathrm{s}$ of Bangladesh. Cyberstalking can be terribly frightening. It alarms, torments and terrorizes a girl. It can destroy friendships, careers; self-image, and confidence.If coupled with real space stalking, cyberstalking, and cyberstalking can lead the victim to far greater physical danger including suicide attempts.

Fifth, unemployment in our country is one of the causes of violence against women. It was mostly seen that men and women are not properly employee according to their qualification. As a result, VAW and crime are increasing day by day.

Sixth, psychopaths contend that offenders lend into criminality on account of functional deviations and mental conflicts. Freud explained mental conflicts in the personality of criminals in terms of 'id', 'ego', and 'superego' He asserted that 'id', generates basic biological and physiological urges and impulse in a person such as sexual desire, hunger, affection for kith and kins, lust for power etc. While ego refers to the conscious personality of which the individuals are aware.Although the desire for sex and hunger are basic urges of a person yet he is all the time conscious that only the righteous means to fulfill these desires protect his personality and any deviation from the normal course shall cast aspersions on his personality.

Lastly, men and Women lend into criminality because they cannot foresee the possible consequence of their acts and are unable to adjust to the complexities of modern life. Their incapability to distinguish between right and wrong or to four see the danger of defection is yet another cause of their criminal behavior.

\subsection{Preventive Measure}

Combating of VAW implies an ecological interpretation of sociological problems. Therefore, in order to hold in check the incidence of crime, the conditions conducive to criminality must also be kept under control.

There is a need for 'Socializing' the administration of criminal justice by greater public participation and invention by representations of the community, both in criminal court proceedings and in the execution of sentences. Thus criminal justice and the community must be brought closer together since these who judge and those who are judged are both parts of the society. Social participation in the administration of criminal justice is possible through the introduction of the jury system, honorary magistrates, people's assessors, technical advisers and administrative boards.

\subsection{Laws to Combat VAW}

Observing the frequency and expansion of VAW, there have been continuous discussions about the enactment of the law in this regard.Special laws have been enacted for preventing domestic violence. These are:

- In Bangladesh the Domestic Violence (Prevention and Protection) Act, 2010 is a positive initiative by the government for addressing domestic violence against women.In case of physical or psychological abuse for dowry, women can take resort to the Act.

- The dowry prohibition Act 1980 provides, demanding dowry a punishable offense.

- In 2009, HCD has issued few directives (BNWLA Vs Bangladesh, 14 BLC HCD 694) which have been treated as a law to ensure the security of women at the workplace in absence of any special Law. 
- The Nari Shishu Nirjaton Daman Ain, 2000 has been enacted to protect women and children from private and public offenses committed against them.

- The Information and Communication Technology Act, 2006 (ICTA) and The Pornography Control Act, 2012(PCA) are important to deal with cyber crimes. Beside these special Laws we have some ordinary laws like Penal Code 1860, also ensured crime or violence against women.

- It can be noted that existent of law, by itself, is not enough to deal with the issue. It needs education of the people, awareness of the people and above all know about the laws.

\subsection{International Perspective}

The Vienna Declaration focuses upon the rights of women as human rights. The Declaration notes:

The human rights of women and of the girl child are an inalienable, integral and indivisible part of human rights. The full and equal participation of women in political, civil, economic, social and cultural life, at the national, regional and international levels, and the eradication of all forms of discrimination on grounds of sex are priority objectives of the international community.In order to overcome this lawlessness, the United Nations General Assembly adopted a Declaration on the Elimination of Violence Against Women.

The Declaration provides an expansive definition of the term 'Violence against Women' taking it to mean:

'Any act of gender-based violence that results in, or is likely to result in physical, sexual or is psychological harm or suffering to women, including threats of such acts, certain or arbitrary deprivation of liberty, whether occurring in public or in private life.' The declaration calls upon all states to condemn violence against women and not to invoke any custom, tradition or religious consideration to justify the continuation of any such violence. The provision is particularly aimed at those societies which continue to justify such policies as female circumcision, sati or dowry as part of the divine ordinance or an integral part of their culture and traditions.

The Convention on the Elimination of All Forms of Discrimination against women has been described as the international Bill of rights for women. Its many positive aspects include courage of a family comprehensive range of rights and a useful state reporting mechanism which has more recently been supplemented by an individual complaint procedure.

"End Violence against Women and Girl Child" was a 16 Days of Activism against Gender-Based Violence Programme in 2015. There were some Principles.

- The inclusion of Chapter on morality and values and puberty to be included.

- Widespread awareness complains regarding the contribution of women in family, society, and state.

- Change of age-old attitude towards in society.

- Increasing participation of women in politics and administration.

- Making education up to HSC free for girls.

- Recognition of the economic value of women's households work.

- Recognizing that women are also a human being and ensuring their right to a life of dignity.

- Making anti-GBV Committees active.

- Identifying the role of schools in preventive child marriage.

- Messages regarding GBV, child marriage etc can be imparted through cartoons and dreams. 
- Eve-teaser should be boycotted socially.

- Co-education will help change the attitude of boys towards girls which should start from primary level.

- There should be Counselor and a Doctor in each school.

Apart of laws, activism from time to time such as the above is important for educated people and enforcement of laws.

\section{Conclusion}

To achieve our goal of combating violence against women, we need to undertake some mechanisms which will make our society from free of VAW. Only law enforcement authority will not able to achieve this goal. We must make aware of this problem and its solution to family society and state. Nowadays there are some NGOs (BNWLA, ASOK etc.) working along the lines. The awareness program should begin from the schools and higher educational institutions.

\section{References}

Agarwal R.S: Prevention of Crime (1977 Ed.)P-46

Article 4, The Vienna Declaration and Program of Action adopted by the world conference on Human Rights (1993).

Dr.N.V Paranjape; Criminology and Penology, Tenth Edition, page - 45

For a multitude examples of the literature see H.J Steiner and P.Alstone (eds). International Human Rights in Context: Law, Politics, Morals: Text and Materials, $2^{\text {nd }}$ edition, Oxford: Clarendon Press,2000; pp:408438

Silving: "Rule of Law in Criminal Justice”. In Essays In Criminal Science (1961 Ed), Chap.5 GA Res. 48/104 of 20 December 1993.

See RVR (A Husband)(CA(Crime: Div)Court of appeal (Criminal Division ) March 14, 1991; concern has been expressed on the subject of marital rape, see, e.g, Concluding observation/comments by Human Rights Committee for Uzbekistan 26/04/2011; Egypt's $3^{\text {rd }}$ and combined $4^{\text {th }}$ and $5^{\text {th }}$ periodic report ,CEDAW /CIEGY/3 and CEDAW/C/EGY at its $492^{\text {nd }}$ and $493^{\text {rd }}$ meetings (4-19) January 2001.

Schuler, S. R., Hashemi, S. M., Riley, A. P., \& Akhter, S. (1996). Credit programs, patriarchy and men's violence against women in rural Bangladesh. Social science \& medicine, 43(12), 1729-1742.

The Daily Star, Tuesday, December 29, 2015, P-11

The Daily Star, Thursday, December 29, 2015 "End Violence against Women and Girl Child".

The Daily Star, Tuesday, March 10, 2015, Cyber Crimes, Are women the main target?

McMillan, L. (2007) Feminists Organising Against Gendered Violence, New York: Palgrave.

Naved, R. T., \& Persson, L. Å. (2005). Factors associated with spousal physical violence against women in Bangladesh. Studies in family planning, 36(4), 289-300.

Khan, N. T., Begum, A., Chowdhury, T. M. J., Das, B. K., Shahid, F., Kabir, S., \& Begum, M. (2017). Violence against women in Bangladesh. Delta Medical College Journal, 5(1), 25-29.

Reilly, N. (2009) Women's Human Rights - Seeking Gender Justice in a Globalizing Age, Cambridge: Polity.

Note

Note 1: CEDAW -second general recommendation (No. 19) on VAW in 1992 defined gender-based violence as a form of discrimination.

\section{Copyrights}

Copyright for this article is retained by the author(s), with first publication rights granted to the journal.

This is an open-access article distributed under the terms and conditions of the Creative Commons Attribution license (http://creativecommons.org/licenses/by/4.0/) 